\title{
“Kampung asi" establishment and its effect on exclusive breastfeeding coverage
}

\author{
Isyti'aroh $^{1}$, Windha Widyastuti ${ }^{2}$ \\ 1,2 Department of Maternity Nursing, University of Muhammadiyah Pekajangan Pekalongan Central Java, Indonesia
}

\begin{tabular}{l}
\hline ARTICLE INFO \\
\hline Article history: \\
Received: August 9, 2020 \\
Revised: August 20, 2020 \\
Accepted: August 30, 2020 \\
\hline
\end{tabular}

Keywords:
Exclusive breastfeeding,
kampung ASI, Paweden

kampung ASI, Paweden

\begin{abstract}
There have been many efforts to increase the coverage of exclusive breastfeeding. However, the result has not been significant. The purpose of this study was to determine the effect of Kampung ASI i.e breastfeeding villages establishment on exclusive breastfeeding coverage in Paweden village Pekalongan regency, Central Java, Indonesia. The research metod used quasy experiment. Data collection used total sampling technique. The research instrument used a questionnaire. The data were processed using Mann Whitney test. The results showed that before establishment of the Kampung ASI, the coverage of exclusive breastfeeding among 36 babies aged 0-6 months, were $41.9 \%$, then increase to be $78.6 \%$ after the establishment. The results of the Mann Whitney test showed a value of $\alpha 0.578$. The conclusion of the study was the establishment of Kampung ASI had no effect on the coverage of exclusive breastfeeding. Suggestions for health workers are always making innovative programs to increase exclusive breastfeeding coverage.
\end{abstract}

This work is licensed under a Creative Commons Attribution 4.0 International License.

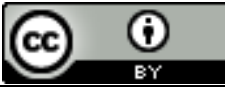

\author{
Corresponding Author: \\ Windha Widyastuti, \\ Department of Maternity Nursing \\ University of Muhammadiyah Pekajangan \\ Pekalongan Central Java, Indonesia
}

\section{INTRODUCTION}

The Ministry of Health of Indonesia, through basic health research (RISKESDAS) in 2018, has recorded the coverage of exclusive breastfeeding nationally. Nationwide exclusive breastfeeding coverage for infants aged 0-5 months was 62.2\% [1]. In Central Java Province coverage for infants aged 0-5 months was $63.31 \%$ [2]. This figure showed that there were still around $39.8 \%$ of babies who are not exclusively breastfed in Indonesia. In fact, babies who are not exclusively breastfed have higher morbidity and mortality compared to babies who are exclusively breastfed. Likewise, the time of breastfeeding at the beginning of the baby's birth (early breastfeeding), the sooner breastfeeding lead to the lower of mortality [2].

There are several reasons for the low coverage of exclusive breastfeeding. Basic Health Research conducted by the Ministry of Health of the Republic of Indonesia in 2018 found the reasons of it among children aged 0-23 months who had not /had never been breastfed was problems in the process of expressing breastmilk (65.7\%), children could not breastfeed (6.6\%), bother $(2.2 \%)$, separated care $(8.4 \%)$, medical reasons $(5.7 \%)$, separated children from their mother $(5.4 \%)$, the mother died $(1.5 \%)$ and also other reasons (4.5\%). Research at Puskesmas Buaran, Pekalongan Regency, Central Java Province, Indonesia showed that the failure of exclusive breastfeeding because of a lack of knowledge about exclusive breastfeeding and false myths about breastfeeding and breastmilk [3].

Increased coverage of exclusive breastfeeding must always be pursued. The government of the Republic of Indonesia through the Ministry of Health has issued a health decree concerning to offer breast milk exclusively to babies aged 0-6 months with number 450/MENKES/SK/ VI/2004. It advice mother to continue offering breastmilk until 2 years with suitable additional foods [4]. Unfortunetly, the implementation has not been implemented optimally. It is necessary to make innovations from several parties who care about the future of the nation so that babies aged 0-6 months get exclusive breastfeeding. 
One of the innovations made was ordering the breastfeeding villages. The formation of the breastfeeding villages in Paweden village, Buaran District, Pekalongan Regency, Central Java Province, Indonesia was initiated by the Buaran Community Health Center together with University of Muhammadiyah Pekajangan Pekalongan in 2018. The work program of the breastfeeding villages was recruiting cadres in each neighborhood (RT), giving them training about lactation management, offering education about breastfeeding to pregnant and nursing mothers, breastfeeding counseling services, and orders for breastfeeding support figures. Evaluation of breastfeeding villages, breastfeeding is an evaluation of the assessment of breastfeeding villages orders of ASI and 6 months thereafter.

\section{RESEARCH METHOD}

The research method used quasi-experimental study design. This study conducted at Buaran PHC in Pekalongan Regency. The samples were 38 babies aged 6 months who were recorded before and after the intervention "Kampung ASI" were 41 babies aged 6 moths. The inclussion criteria were the babies were biological children and do not have disabilities that make them difficult to breastfeed. The exclusion criteria were the mother's have HIV/AIDS and have complication during childbird so that can't breastfeed. Data were collected by total sampling technique The research instrument used a questionnaire containing demongographical data and infant nutrition from 0-6 months. The data obtained were tested by Mann Whitney. Intervention in this research was the establishment of Kampung ASI i.e breastfeeding villages. The program that carried out after the establishment of Kampung ASI were the forming of breastfeeding cadres in each area around the village, then training and mentoring the breastfeeding cadres. In addition, the programs also included providing education about breastfeeding to pregnant and lactating women, breastfeeding counseling services, and forming breastfeeding support figures.

\section{RESULTS AND DISCUSSIONS}

The study found that average age of the father and mother of the baby at the before and after of Kampung ASI establishment was in the productive age range. However, there was still exist a mother's age above 35 years which is included in the category of vulnerable age in reproduction. Judging from the level of education, most of them have low education. In addition, most of them are unemployee, multiparous, and live in nuclear families. This result is in line with the research of Jessri, Farmer, Maximova, Willows and Bell [5] in Canada regarding the predictors of exclusive breastfeeding. The study found that, the mean age of the respondents were 31 years. However, from the status of education, employment and parity, the study found that most of the respondents were college graduates, worked and were primiparous. These results mean that in developed countries such as Canada, the level of education of the people mostly high, and the primiparous women mostly have a job. The type of family in this study is mostly nuclear family. The nuclear family means a family consisting of father, mother and child. Research in India [6] also showed data on family types which were mostly in nuclear families. The nuclear family is one of the cause of the cessation of exclusive breastfeeding.

The test to determine the effect of Kampung ASI establishment with exclusive breastfeeding coverage used Mean Withney. It showed the result of $p$ value was 0.578 that means the result was greater than $\alpha 0.05$ as in Table 2. It can be concluded that the Kampung ASI establishment hads no effect on increasing the coverage of exclusive breastfeeding. However, there was an increase in the percentage of exclusive breastfeeding coverage after the Kampung ASI establishment.

Table 2. Distribution of exclusive breastfeeding coverage

\begin{tabular}{lccc}
\hline Breastfeeding coverage & Frequency & Percentage & p-value \\
\hline Before $(\mathbf{n}=\mathbf{3 8})$ & & & \\
Exclusive & 18 & $47.4 \%$ & \\
Cessation & 20 & $52.6 \%$ & \\
After (n=42) & & & 0.578 \\
Exclusive & 9 & $21.4 \%$ & \\
Cessation & 33 & $78.6 \%$ & \\
\hline
\end{tabular}

Kampung ASI is a program initiated by the Buaran PHC. It held in Pekalongan Regency in collaboration with University of Muhammadiyah Pekajangan Pekalongan in 2018. Activities began with the formation of breastfeeding cadres, then training the lactation management to them. After that, Kampung ASI was launched. The program continued by coaching breastfeeding cadres by lecturers from the University of Muhammadiyah Pekajangan Pekalongan. The coaching included of delivering the way to give health education for pregnant and breastfeeding mothers about breastfeeding, and the formation of supporting figures for Exclusive Breastfeeding. The formation of the Kampung ASI as a part of community service has also been carried out in Rambipuji Village, Rambipuji District, Jember Regency, East Java, Indonesia. The results 
obtained an increase in partners' understanding of exclusive breastfeeding, the benefits and importance of breastfeeding support groups. Moreover, $100 \%$ of partners had willing and committed to be the member of breastfeeding support groups then realized breastfeeding villages [7]. In this program, evaluation of exclusive breastfeeding coverage is not carried out.

Research about exclusive breastfeeding in Kampung ASI at Kertosono District, Nganjuk Regency, East Java, Indonesia was also conducted in 2018 [7]. This study aimed to determine the factors of age, education level, employment status, income, knowledge, attitudes, behaviors that affect on exclusive breastfeeding among 104 respondents. The results showed that attitudes and behaviors influenced successfullness of exclusive breastfeeding. The difference between the research and this study is not examine the coverage of exclusive breastfeeding before and after the establishment of breastfeeding villages, so that it could not analyze the effect of the formation of breastfeeding villages on exclusive breastfeeding coverage.

The result of this study found that the establishment of Kampung ASI had not significantly increased the coverage of exclusive breastfeeding. It may caused by other factors that influence the mother to stop giving exclusive breastfeeding. Research on "Prevalence and determinants of cessation of exclusive breastfeeding among 140 primi-para rural Indian mothers" showed several factors that influenced mothers to stop breastfeeding, such as insufficient breast milk secretion (37.5\%), maternal sickness. (12.5\%) and infant illness $(12.5 \%)$. The nuclear family structure, caesarean delivery and low birth weight babies were significantly associated with cessation of exclusive breastfeeding. The risk of cessation of exclusive breastfeeding was of 4.5 and 2.5 times higher with maternal nuclear family structure and infant with low birth weight [8].

Research by Tama and Astutik, on Exclusive Breastfeeding Survival And Factors Related to Early Breastfeeding Cessation in Indonesia among 1088 mothers with babies aged 6-12 months found that the cumulative survival probability of exclusive breastfeeding was significantly different based on mother's age, mother's education, marital status, place of delivery, and antenatal care [9]. Meanwhile, the factors that related to mothers to stop breastfeeding were place of delivery and low knowledge about breastfeeding. Mothers who given birth in health services taking longer to provide exclusive breastfeeding compared to mothers who given birth at home. Another Indonesian study with the number of respondents was 3,117 urban mothers and 2,074 rural mothers who drawn from 20 provinces in Indonesia, also showed that maternal unemployment and high family socioeconomic status were associated with longer duration of breastfeeding [10].

To increase the coverage of exclusive breastfeeding, peer counselors or peer support are also needed. Breastfeeding peer support is actually advocated in health policy and breastfeeding problems as a way of promoting equality to access health care through a community-oriented and health promotional. Study about Building social capital through breastfeeding peer support in North-West England showed how the peer support service facilitated 'bonds' with its members, between women who accessed the services; how the service 'bridges' with individuals from different interests and backgrounds, and how 'links' were forged with those in authority to gain access and reach to women and to promote a breastfeeding culture [11]. Based on the study result informed that community empowerments for example establishment of Kampung ASI i.e. breastfeeding village, were needed to increase coverage breastfeeding.

The qualitative study about empowerment in breastfeeding also found thath proper quality and quantity of mother's milk relate to knowledge and skill of breastfeeding. As well as overcoming breastfeeding problems could to tend to stabilization empowerment in breastfeeding. The study showed that participants' belief in the value of breastfeeding strengthened the empowerment in breastfeeding and presenced of perceived comprehensive support for breastfeeding facilitates empowerment in breastfeeding continuance [12]. Many systematic reviews showed that breastfeeding support could increases duration and exclusivity of breastfeeding, both in aterm healthy newborns and in preterm infants [13].

Efforts to increase the coverage of exclusive breastfeeding must continue, because the benefits of breastfeeding for babies and mothers have been proven from many studies. For babies, breastfeeding can be protective factor for many infectious disease such as atopic and cardiovascular diseases as well as for leukemia, necrotizing enterocolitis, celiac disease, and inflammatory bowel disease. Breastfeeding also has a positive impact on improving IQ, neurodevelopment, reducing the risk of attention deficit disorder, generalized developmental and behavioral disorders [14]. Breastfeeding is environmentally friendly, because it does not leave waste from ecological footprint in its production and consumption. In mothers, breastfeeding influences mood, affect, stress, and maternal care [15].

The government, health workers, family and the community must be supported to keep the continuity of breastfeeding for increasing the coverage of exclusive breastfeeding. In addition, coordination with policy consensus and strong political action are indispensable to integrate breastfeeding support into healthcare and society, effectively [16]. In Indonesia, nationality coordination to continuum of breastfeeding support can be implemented by the ministry of health of Indonesia. A review of scientific articles showed many factors that influenced on success of exclusive breastfeeding. Likewise with cessation of exclusive breastfeeding, there 
were many factors that contributed. Therefore, efforts to increase exclusive breastfeeding must be conducted in a variety of innovative and creative ways.

\section{CONCLUSION}

The conclusion of this study is the establishment of Kampung ASI i.e. breastfeeding village has no effect on increasing the coverage of exclusive breastfeeding. It is suggested that health services should taking collaboration with health education institutions to create innovative programs to increase the coverage of exclusive breastfeeding.

\section{Acknowledgements}

Thank you very much to the local government of Pekalongan Regency, the Head of PHC of Buaran, the Head of Paweden Village, the Chancellor and all staff at University of Muhammadiyah Pekajangan Pekalongan who have facilitated the implementation of the research..

\section{REFERENCES}

[1] The Ministry of Health of Indonesia (Kementrian Kesehatan Republik Indonesia), "Raport of basic health reseach 2018," 2018. [Online]. Available: https://www.litbang.kemkes.go.id/laporan-risetkesehatan-dasar-riskesdas/.

[2] A. K. Debes, "Time to initiation of breastfeeding and neonatal mortality and morbidity: a systematic review," BMC Public Health, vol. 1, no. 9, p. 13, 2013.

[3] Isyti'aroh, "Prediktor Kegagalan Menyusui Eksklusif: Studi di Puskesmas Buaran Kabupaten Pekalongan Jawa Tengah Indonesia," Jurnal Keperawatan Indonesia, vol. 22, no. 1, pp. 65-73, 2019.

[4] The Minister of Health of Indonesia (Kementrian Kesehatan Republik Indonesia), "Decree of the minister of health of the republic Indonesia," 2009. [Online]. Available: https://aimiasi.org/storage/app/media/pustaka/Dasar-Dasar Hukum/Kepmenkes No. 450 Th. 2009.

[5] M. Jessri, A. P. Farmer and N. Willows, "Predictors of exclusive breastfeeding: Observations from the Alberta pregnancy outcomes and nutrition (APrON) study," BMC pediatrics, vol. 1, no. 3, p. 77, 2013.

[6] R. Mohite, "Prevalence and determinants of cessation of exclusive breastfeeding among primi-para rural Indian mothers," International Journal Of Community Medicine And Public Health, vol. 6, no. 1, pp. 314-319.

[7] D. Kurniawati, "Sosialisasi air susu ibu (asi) dalam mewujudkan kampung asi," Journal prosiding pkm-csr, vol. 1, pp. 845-849, 20018.

[8] H. S. Agustin and I. M. Zain, "Kajian pemberian asi eksklusif pada kampung asi di kecamatan Kertosono Kabupaten Nganjuk," Jurnal pendidikan geografi, pp. 1-8, 2018.

[9] T. D. Tama, "Astutik, E. Exclusive Breastfeeding Survival And Factors Related to Early Breastfeeding Cessation in Indonesia," Advances in Health Science Research (AHSR), vol. 7, pp. 183-186, 2019.

[10] E. Yohmi, "Prevalence of exclusive breastfeeding in Indonesia: a qualitative and quantitative study," PI, vol. 6, no. 55, pp. 302-8, 2016.

[11] G. Thomson, "Building social capital through breastfeeding peer support: insights from an evaluation of a voluntary breastfeeding peer support service in North-West England," International Breastfeeding Jounal, vol. 10, no. 15, 2015.

[12] Z. Heidari, "Empowerment in breastfeeding as viewed by women: A qualitative study," Journal of education and health promotion, vol. 6, no. 33, 2017.

[13] R. Bellù and C. Manuela, "Breastfeeding promotion: evidence and problems," La Pediatria medica e chirurgica : Medical and surgical pediatrics, vol. 2, p. 39, 2017.

[14] S. I. Rosin and . Z. Grković, "Towards integrated care in breastfeeding support: a cross-sectional survey of practitioners perspectives," International Breastfeed Journal, vol. 11, no. 15, pp. 1-17, 2016.

[15] Krol, M. Kathleen and T. Grossmann, "Psychological effects of breastfeeding on children and mother," Bundesgesundheitsblatt, vol. 61, no. 18, pp. 977-985, 2018.

[16] P. Brahm and V. Verónica, "The benefits of breastfeeding and associated risks of replacement with baby formulas," Revista chilena de pediatria, vol. 88, no. 1, pp. 7-14, 2017. 